\title{
A First Generation Total Synthesis of (+)-Salicylihalamide A
}

\author{
Amos B. Smith, III* Junying Zheng
}

Department of Chemistry, Laboratory for Research on the Structure of Matter, and Monell Chemical Senses Center, University of Pennsylvania, Philadelphia, PA 19104, U.S.A.

E-mail: smithab@sas.upenn.edu

Received 1 February 2001

Dedicated to Professor Ryoji Noyori with admiration and respect for his many seminal contributions to chemistry.

\begin{abstract}
An efficient total synthesis of (+)-salicylihalamide (1) is described. The synthetic strategy features a highly $E$-selective ringclosing metathesis to construct the 12-membered salicylihalamide A macrocycle and a practical method for installation of the labile ene-hepta- $(Z, Z)$-dienamide side chain, which relies on a Curtius rearrangement to forge the $\mathrm{C} 18-\mathrm{N}$ bond with subsequent $\mathrm{N}$-acylation.
\end{abstract}

Key words: salicylihalamide, total synthesis, macrocycles, metathesis, Curtius rearrangement

In 1997 Boyd and co-workers ${ }^{1}$ reported the isolation and structural elucidation of salicylihalamides A and B, novel secondary metabolites produced by a marine sponge of the genus Haliclona. Since their discovery, a number of structurally similar bioactive metabolites have been isolated and characterized, including the apicularens, ${ }^{2}$ lobatamides, ${ }^{3}$ and oximidines. ${ }^{4}$ Each of these structures possesses a medium-sized macrolide ring engendering a salicylate moiety and a dienylenamide sidechain. Salicylihalamide A displayed potent cytotoxicity when screened against the NCI 60-cell human tumor line assay, with a mean panel $\mathrm{GI}_{50}$ value of $15 \mathrm{nM} .^{1}$ Of particular import, however, the mean-graph profiles for the salicylihalamides obtained from COMPARE pattern-recognition analysis ${ }^{5}$ suggested a unique mode of action apart from known antitumor compounds within the NCI database. Thus, owing to the unique, potent cytotoxicities of the salicylihalamides, as well as their scarcity and their novel structural features, particularly the highly unsaturated enamide sidechain, a strong impetus for total synthesis presented itself.

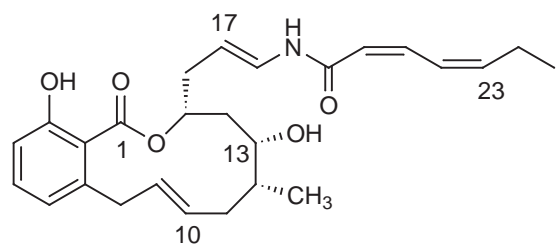

(+)-Salicylihalamide A (1): 17(E)

(+)-Salicylihalamide B (2): 17(Z)

Figure
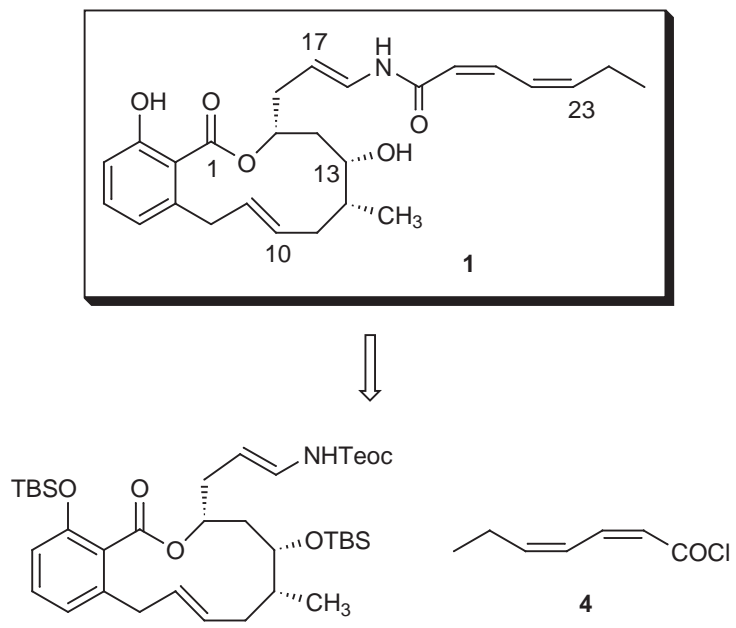

3

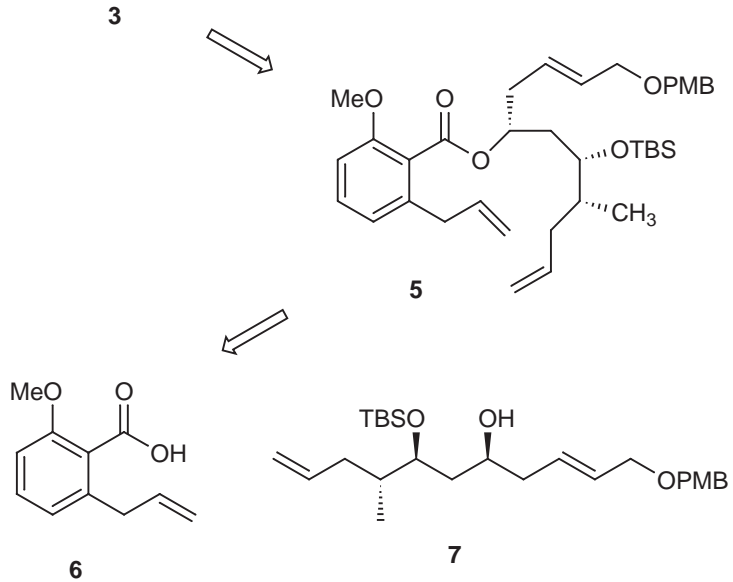

Scheme 1

Recently De Brabander and co-workers ${ }^{6}$ reported the first, and to date only, total synthesis of (+)-salicylihalamide A (1); this achievement resulted in reassignment of the absolute configuration as $12 S, 13 R, 15 S$. A number of other groups also have reported synthetic efforts towards salicylihalamides. ${ }^{7,8}$ Herein we disclose our first generation, stereocontrolled total synthesis of the non-naturally-occurring enantiomer, (+)-salicylihalamide A (1).

We reasoned that the sensitive enamide sidechain would best be installed at a late stage of the synthesis via $\mathrm{N}$-acylation of advanced enecarbamate 3 with $(Z, Z)$-dienyl chloride 4 (Scheme 1). ${ }^{9}$ Further analysis of $\mathbf{3}$ suggested a ring- 
closing metathesis $(\mathrm{RCM})^{10}$ on triene $\mathbf{5}$ would serve both to install the $C(9,10)$ double bond and close the 12-membered macrolide. At the outset of this synthetic venture control of the E-olefinic configuration could not be assured (vide infra). Ester $\mathbf{5}$, in turn, would be available after Mitsunobu union ${ }^{11}$ of secondary alcohol 7 with the salicylic acid derivative 6 .

The synthesis of $\mathbf{6}$ began with conversion of known amide $\mathbf{8}^{12}$ (available in two steps from methylsalicylic acid chloride) to iodide $9^{13}$ (Scheme 2). Carboxylic acid $6^{13}$ was then obtained via exposure of the iodolactone 9 to zinc in acetic acid. ${ }^{14}$

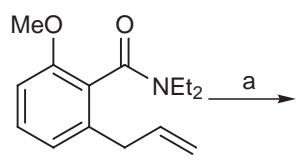

8

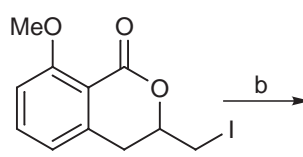

9

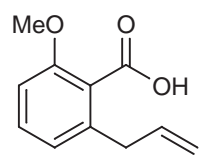

6
Scheme 2 (a) $\mathrm{I}_{2}, \mathrm{THF} / \mathrm{H}_{2} \mathrm{O}, \mathrm{rt}, 65 \%$; (b) $\mathrm{Zn}, \mathrm{HOAc}, 90{ }^{\circ} \mathrm{C}, 73 \%$

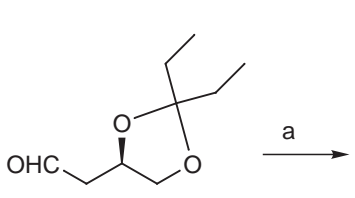

$(-)-10$

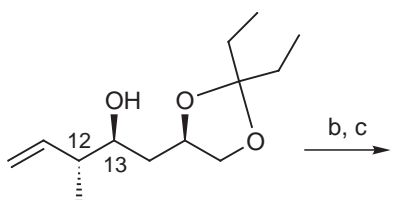

$(-)-11$

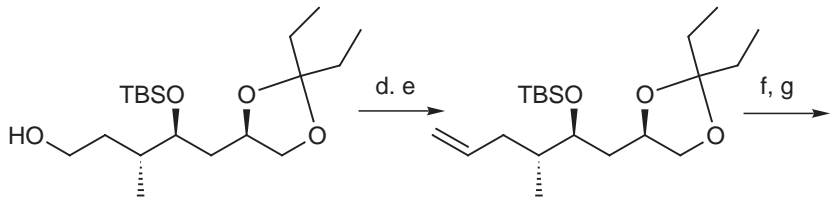

$(-)-12$

$(-)-13$

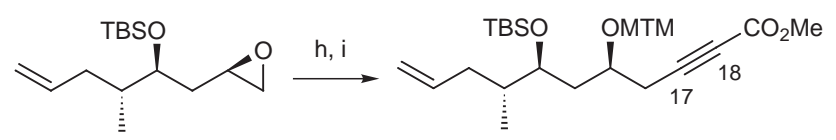

$(-)-14$

$(-)-15$

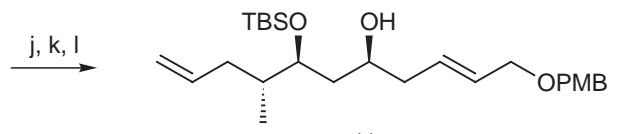

$(-)-7$

Scheme 3 (a) $(S, S)$-diisopropyl tartrate $(E)$-crotylboronate, $\mathrm{PhCH}_{3}$, $-78{ }^{\circ} \mathrm{C}, 88 \%, 90 \%$ de; (b) TBSOTf, 2,6-lutidine, $-78{ }^{\circ} \mathrm{C}, 99 \%$; (c) $\mathrm{i}$ : I. 9-BBN, THF, reflux; ii: $2 \mathrm{~N} \mathrm{NaOH}, \mathrm{H}_{2} \mathrm{O}_{2}, 84 \%$; (d) DMSO, $(\mathrm{COCl})_{2}, \mathrm{Et}_{3} \mathrm{~N},-78{ }^{\circ} \mathrm{C}, 96 \%$; (e) methyltriphenylphosphonium iodide, $\mathrm{NaHMDS},-78{ }^{\circ} \mathrm{C}$ to rt, $81 \%$; (f) $50 \%$ aq. TFA $/ \mathrm{CH}_{2} \mathrm{Cl}_{2}, \mathrm{rt}, 90 \%$; (g) tosyl-imidazole, $\mathrm{NaH}, 81 \%$; (h) methylpropiolate, $n$-BuLi, $\mathrm{BF}_{3} \bullet \mathrm{OEt}_{2},-78{ }^{\circ} \mathrm{C}, 94 \%$; (i) DMSO, $\mathrm{Ac}_{2} \mathrm{O}, \mathrm{rt}, 96 \%$; (j) $\mathrm{LiAlH}_{4}, \mathrm{THF}$, rt, 77\%; (k) NaH, PMBCl, TBAI, DMF, rt, 91\%; (l) $\mathrm{AgNO}_{3}, 2$,6-lutidine, THF, rt, $91 \%$
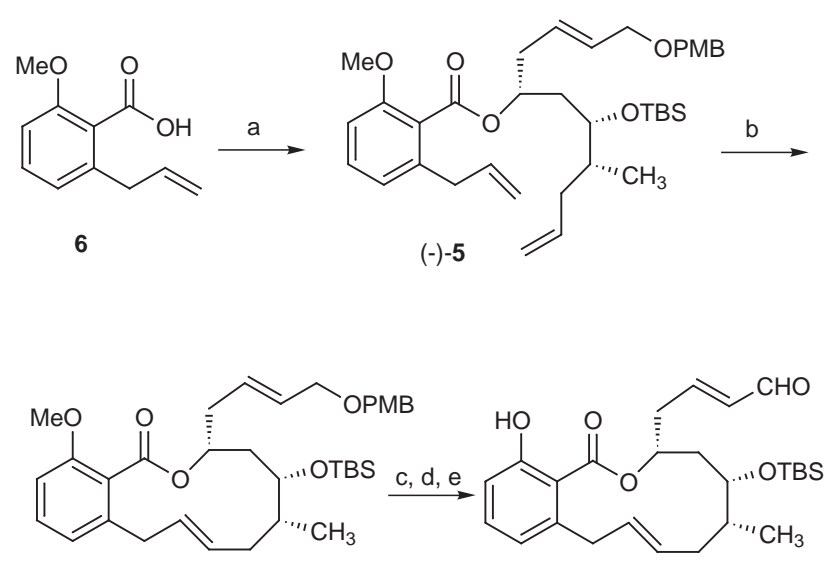

$(+)-16$

$(+)-17$

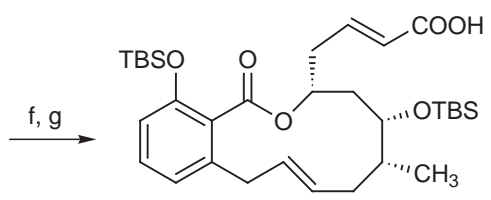

$(-)-18$

Scheme 4 (a) $\mathrm{PPh}_{3}, \mathrm{DEAD},(-)-7, \mathrm{PhH}, \mathrm{rt}, 84 \%$; (b) $10 \mathrm{~mol} \%$ $\left(\mathrm{Cy}_{3} \mathrm{P}\right)_{2} \mathrm{Cl}_{2} \mathrm{Ru}=\mathrm{CHPh}, \mathrm{CH}_{2} \mathrm{Cl}_{2}, \mathrm{rt}, 86 \%$; (c) DDQ, $\mathrm{CH}_{2} \mathrm{Cl}_{2}, \mathrm{pH} 7$ buffer, rt, 97\%; (d) Dess-Martin periodinane, $\mathrm{CH}_{2} \mathrm{Cl}_{2}, \mathrm{rt}, 98 \%$; (e) $\mathrm{BBr}_{3}$, $\mathrm{CH}_{2} \mathrm{Cl}_{2},-78{ }^{\circ} \mathrm{C}, 82 \%$; (f) $\mathrm{NaClO}_{2}, \mathrm{NaH}_{2} \mathrm{PO}_{4}$ buffer, $t$-BuOH, 2methyl-2-butene, rt, 97\%;(g) i. TBSOTf, $\mathrm{Et}_{3} \mathrm{~N}, \mathrm{CH}_{2} \mathrm{Cl}_{2}$, rt, ii. $\mathrm{K}_{2} \mathrm{CO}_{3}$, $\mathrm{MeOH} / \mathrm{THF} / \mathrm{H}_{2} \mathrm{O}, \mathrm{rt}, 83 \%$

Our approach to the required coupling partner (-)-7 is presented in Scheme 3. The anti relative stereochemistry at $\mathrm{C}(12,13)$ was set via Roush crotylboration ${ }^{16}$ of known aldehyde (-)-10 ${ }^{15}$ to furnish $(-)-\mathbf{1 1} ;{ }^{13}$ the diastereomeric excess was $90 \%$. Protection of (-)-11 as the tertbutyldimethylsilyl ether, followed by a 3-step homologation involving hydroboration, ${ }^{17}$ Swern oxidation ${ }^{18}$ and Wittig methylenation ${ }^{19}$ then furnished olefin $(-)-\mathbf{1 3} .{ }^{13}$ The 1,2 diol was next revealed by exposure of diethylketal $(-)-\mathbf{1 3}$ to aqueous trifluoroacetic acid; ${ }^{20}$ application of the Kishi epoxide protocol ${ }^{21}$ led to $(-)-\mathbf{1 4}^{13}$ in $73 \%$ yield for the two steps. The future $\mathrm{C}(17)$ and $\mathrm{C}(18)$ enamide carbons were then introduced by treatment of (-)-14 with the lithium anion of methyl propiolate promoted by Lewis acid $\left(\mathrm{BF}_{3} \mathrm{OEt}_{2}\right)^{22}$ to furnish alkynoate (-)-15. ${ }^{13}$ Arrival at the $p$-methoxybenzyl (PMB) ether coupling partner (-)-7 was achieved via protection of the secondary alcohol as the methyl-thiomethyl (MTM) ether, ${ }^{23} \mathrm{LAH}$ reduction to the homo allylic alcohol followed by protection as the PMB ether, ${ }^{24}$ and silver-mediated ${ }^{23}$ removal of the MTM moiety.

Union of acid $\mathbf{6}$ and alcohol (-)-7 was achieved via the Mistunobu protocol ${ }^{11}$ (Scheme 4) to provide the olefin metathesis substrate $(-)-5 .{ }^{13}$ To our delight treatment of a dichloromethane solution of (-)-5 $(0.008 \mathrm{M})$ with the Grubbs catalyst $\left[\left(\mathrm{Cy}_{3} \mathrm{P}\right)_{2} \mathrm{Cl}_{2} \mathrm{Ru}=\mathrm{CHPh} ;(10 \mathrm{~mol} \%)\right]$ fur- 
nished the salicylihalamide macrolide $(+)-\mathbf{1 6}^{13}$ as an approximate 10:1 mixture of double bond isomers favoring the desired $E$-isomer. ${ }^{25}$ Presumably this stereochemical outcome derives from a combination of the reversible nature of the ring-closing metathesis process ${ }^{26}$ and the thermodynamic stability of the $E$-olefinic configuration in the salicylihalamide macrocycle. Similar selectivity in a ringclosing metathesis was observed by De Brabander and A. Fürstner in their total syntheses of salicylihalamide A. ${ }^{6,7}$

The sequence leading to installation of the enamide side chain began with a two-step conversion of the protected primary allylic alcohol (+)-16 to the corresponding enal (DDQ then Dess Martin periodinane ${ }^{27}$ ). Cleavage of the anisole methyl ether with boron tribromide ${ }^{28}$ provided phenol (+)-17. ${ }^{13}$ Subsequent oxidation of the enal to the carboxylic acid, followed by silylation of both the $\mathrm{C}(3)$ hydroxyl and acid moieties and base-mediated hydrolysis $^{29}$ of the TBS ester furnished carboxylic acid $(-)-18 .{ }^{13}$

In anticipation of the $N$-acylation reaction to install the salicylihalamide sidechain, we turned to the synthesis of Z,Z-dienyl acid chloride 4 (Scheme 5). Ethyl lithium (prepared by lithium-halogen exchange between $t$-BuLi and ethyl iodide) was treated sequentially with $\mathrm{CuBr} \cdot \mathrm{SMe}_{2}$ complex ( 0.5 equivalent), acetylene (1.5 equivalents, introduced as a measured volume of gas) at $-40{ }^{\circ} \mathrm{C}$, and after $20 \mathrm{~min}$ an additional 2.5 equivalents of acetylene at $-10{ }^{\circ} \mathrm{C}$, as described by Taylor and co-workers ${ }^{30}$ for the synthesis of the closely related $Z, Z$-nonadienoic acid. The resulting Z,Z-dienylcuprate was then trapped with carbon dioxide to furnish, after isolation, dienyl acid $\mathbf{1 9}^{13}$ in $20 \%$ yield as a single isomer. Treatment of the latter with oxalyl chloride in the presence of a catalytic amount of DMF generated acid chloride $4 .{ }^{13}$

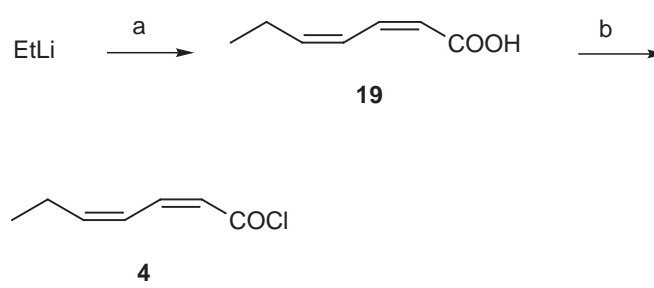

Scheme 5 (a) i. 0.5 eq. $\mathrm{CuBr} \cdot \mathrm{SMe}_{2}, \mathrm{Et}_{2} \mathrm{O},-35^{\circ} \mathrm{C}$, ii. 1.5 eq. acetylene, $-40{ }^{\circ} \mathrm{C}$, iii. 2.5 eq. acetylene, $-10{ }^{\circ} \mathrm{C}$, iv. $\mathrm{CO}_{2}, \mathrm{HMPA},(\mathrm{EtO})_{3} \mathrm{P}$, $20 \%$; (b) $(\mathrm{COCl})_{2}$, cat. DMF, $\mathrm{PhH}, \mathrm{rt}$

With ample quantities of both $\mathbf{4}$ and (-)-18 available, the stage was set for the crucial incorporation of the enamide sidechain. Exploiting the original Overman protocol, ${ }^{31} \mathrm{se}-$ quential treatment of acid (-)-18 (Scheme 6) with $N, N$-diethylisopropylamine and $i$-BuOCOCl in acetone, followed by aqueous sodium azide secured the corresponding acyl azide which upon heating at reflux for 15 min in toluene underwent a facile Curtius rearrangement.
Without isolation the intermediate isocyanate was immediately trapped with 2-(trimethylsilyl)-ethanol to provide enecarbamate $(-)-3^{13}$ in excellent overall yield for the four-step sequence (86\%). ${ }^{32}$ Exposure of (-)-3 to NaHMDS followed by acid chloride $\mathbf{4}$ then proceeded smoothly to furnish (-)-20. ${ }^{13,33}$ This stepwise elaboration of the salicylihalamide sidechain proved to be a high-yielding protocol, and represents a practical method for incorporation of the sidechain of the salicylihalamide system. Final conversion to (+)-salicylihalamide A was achieved upon sequential removal of the Teoc and TBS protecting groups, thereby completing a stereocontrolled total synthesis of the non-naturally-occurring enantiomer of salicylihalamide A (1) ${ }^{13}$ The spectroscopic data for synthetic (+)-salicylihalamide A (1) (e.g., ${ }^{1} \mathrm{H}$ NMR $(500 \mathrm{MHz}),{ }^{13} \mathrm{C}$ NMR (125 MHz), IR, HRMS) were in complete agreement with the published data for (-)-salicylihalamide A, except of course for chiroptic properties.
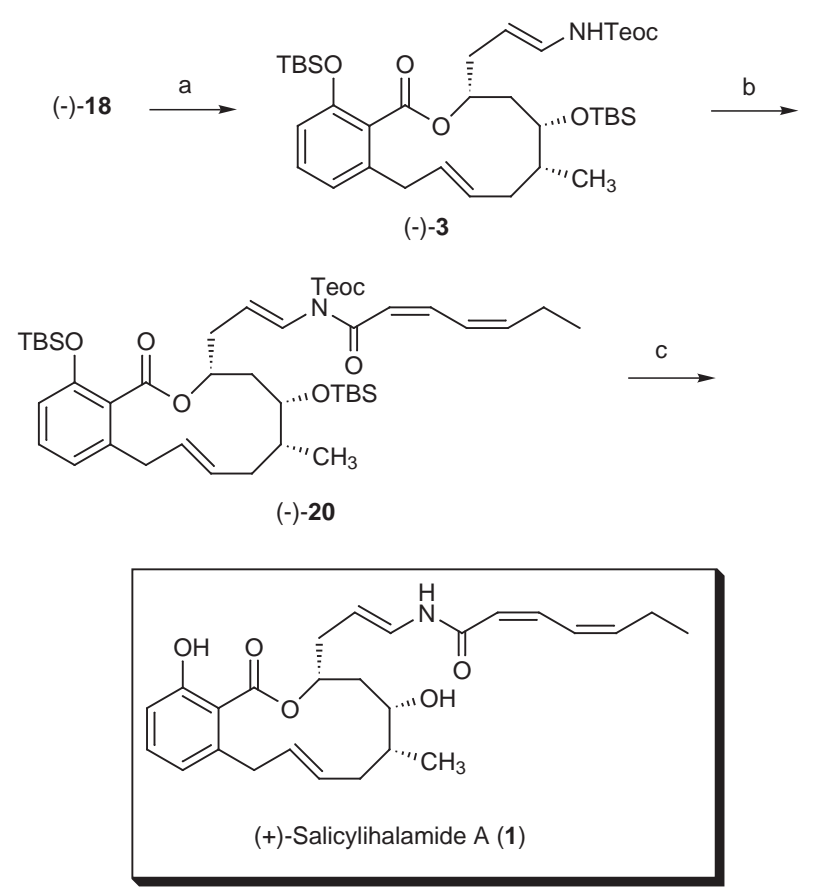

Scheme 6 (a) i. DIPEA, $i$-BuOCOCl, acetone, rt, ii. $\mathrm{NaN}_{3}, \mathrm{H}_{2} \mathrm{O}$, rt, iii. toluene, reflux, iv. 2-(trimethylsilyl)-ethanol, 86\%; (b) NaHMDS, 4, THF, $0{ }^{\circ} \mathrm{C}, 81 \%$; (c) i. TBAF, THF, $0{ }^{\circ} \mathrm{C}$, ii. HF॰pyridine, pyridine/ THF, $40-60 \%$

\section{Acknowledgement}

Financial support was provided by the National Institutes of Health (National Cancer Institute) through grant CA19033. In addition, we thank Dr. George T. Furst and Dr. Rakesh K. Kohli of the University of Pennsylvania Spectroscopic Service Center for assistance in securing and interpreting high-field NMR spectra and mass spectra, respectively. Finally, we thank Dr. R. Michael Corbett for his generous help in the preparation of this manuscript. 


\section{References and Notes}

(1) Erickson, K. L.; Beutler, J. A.; Cardellina II, J. A.; Boyd, M. R. J. Org. Chem. 1997, 62, 8188-8192.

(2) Kunze, B.; Jansen, R.; Sasse, F.; Hofle, H.; Reichenbach, H. J. Antibiot. 1998, 51, 1075-1080. Jansen, R.; Kunze, B.; Sasse, F.; Reichenbach, H.; Hofle, H. Eur. J. Org. Chem. 2000, 913919.

(3) McKee, T. C.; Galinis, D. L.; Pannell, L. K.; Cardellina II, J. H.; Laakso, J.; Ireland, C. M.; Murray, L.; Capon, R. J.; Boyd, M. R. J. Org. Chem. 1998, 63, 7805-7810.

(4) Kim, J. W.; Shin-ya, K.; Furihata, K.; Hayakawa, Y.; Seto, H. J. Org. Chem. 1999, 64, 153-155.

(5) Paull, K. D.; Hamel E.; Malspeis, L. Prediction of Biochemical Mechanism of Action from the In Vitro Antitumor Screen of the National Cancer Institute, in Cancer Chemotherapeutic Agents, ed. Foye, W. O. American Chemical Society, Washington, DC, 1995

(6) Wu, Y.; Esser, L.; De Brabander, J. K. Angew. Chem. Int. Ed. 2000, 39, 4308-4310. Wu, Y.; Seguil, O. R.; De Brabander, J. K. Org. Lett. 2000. 26, 4241-4244.

(7) For synthetic studies on the salicylihlamides, see: Furstner, A.; Thiel, O. R.; Blanda, G. Org. Lett. 2000, 2, 3731-3734. Feutrill, J. T.; Holloway, G. A.; Hilli, F.; Hugel, H. M.; Rizzacasa, M. A. Tetrahedron Lett. 2000, 41, 8569-8572. Georg, G. I.; Ahn, Y. M.; Blackman, B.;Farokhi, F.; Flaherty, P. T.; Mossman, C. J.; Roy, S.; Yang, K. Chem. Commun. 2001, 255-256.

(8) For investigations into syntheses of the salicylihalamide and oximidine sidechains, see: Snider, B. B.; Song, F. Org. Lett. 2000, 2, 407-408. Kuramochi, K.; Watanabe, H.; Kitahara, T. Synlett 2000, 397-399. Shen, R.; Porco, J. A., Jr. Org. Lett. 2000, 2, 1333-1336. Stefanuti, I.; Smith, S. A.; Taylor, R. J. K. Tetrahedron Lett. 2000, 41, 3735-3738.

(9) Shimasaki, H.; Kagechika, H.; Fukasawa, H.; Kawachi, E.; Shudo, K. Chem. Pharm. Bull. 1995, 43(1), 100-107.

(10) Grubbs, R. H.; Chang, S. Tetrahedron 1998, 54, 4413-4450. Furstner, A. Top. Organomet. Chem. 1998, 1, 37-72. Furstner, A.; Seidel,Kindler, N. Tetrahedron 1999, 55, 8215-8230.

(11) Mitsunobu, O. Synthesis 1981, 1-28.

(12) De Silva, S. O.; Reed, J. N.; Billedeau, R. J.; Wang, X.; Norris, D. J.; Snieckus, V. Tetrahedron 1992, 48, 4863-4878. Bibi, M. P.; Jalil Miah, M. A.; Snieckus, V. J. Org. Chem. 1984, 49, 737-742.

(13) The structural assignment for each new compound is in accord with its IR, ${ }^{1} \mathrm{H}(500 \mathrm{MHz})$ and ${ }^{13} \mathrm{C}(125 \mathrm{MHz}) \mathrm{NMR}$ and high resolution mass spectrometric data.

(14) Yoshiharu, T.; Nagata, Y.; Itoh, E.; Hashimoto, M.; Katoh, T.; Terasima, S. Tetrahedron 1997, 53, 10239-10252

(15) Masamune, S.; Ma, P.; Okumoto, H.; Ellingboe, J. W.; Ito, Y. J. Org. Chem. 1984, 49, 2837-2838.

(16) Roush, W. R.; Ando, K.; Powers, D. B.; Palkowitz, A. D.; Halterman, R. L. J. Am. Chem. Soc. 1990, 112, 6339-6348. Roush, W. R.; Palkowitz, A. D.; Ando, K. J. Am. Chem. Soc. 1990, 112, 6348-6359.

(17) Brown, H. C.; Subba Rao, B. C. J. Am. Chem. Soc. 1956, 78, 5694-5695.

(18) Mancuso, A. J.; Huang, S. L.; Swern, D. J. Org. Chem. 1978, 43, 2480.

(19) Wittig, G.; Geissler, G. Liebigs Ann. Chem. 1953, 580, 44-57.

(20) Shing, T. K. M.; Tam, E. K. W. Tetrahedron: Asymmetry 1996, 7, 353-356.

(21) Hong, C. H.; Kishi, Y. J. Am. Chem. Soc. 1991, 113, 96939694.

(22) Yamaguchi, M.; Hirao, I. Tetrahedron Lett. 1983, 24, 391394.
(23) Corey, E. J.; Bock, M. G. Tetrahedron Lett. 1975, 38, 32693270. Pojer, P. M.; Angyal, S. J. Aust. J. Chem. 1978, 31, 1031-1040.

(24) Takaku, H.; Kamaike,K. Tsuchiya, H. J. Org. Chem. 1984, 49, 51-56

(25) To a solution of the Grubbs catalyst $\left(\mathrm{Cy}_{3} \mathrm{P}\right)_{2} \mathrm{Cl}_{2} \mathrm{Ru}=\mathrm{CHPh}$ (17.2 $\mathrm{mg}, 0.0209 \mathrm{mmol}, 10 \mathrm{~mol} \%)$ in dry $\mathrm{CH}_{2} \mathrm{Cl}_{2}(26 \mathrm{~mL})$ was added a solution of $(-)-5(130 \mathrm{mg}, 0.209 \mathrm{mmol})$ in $\mathrm{CH}_{2} \mathrm{Cl}_{2}$ $(3 \mathrm{~mL})$. The reaction mxture was stirred for 40 minutes at ambient temperature and poured into $\mathrm{H}_{2} \mathrm{O}(20 \mathrm{~mL})$. The organic phase was washed with brine, dried over $\mathrm{MgSO}_{4}$, filtered, and concentrated. Flash chromatography (hexanes/ ethyl acetate, 15:1) afforded (+)-16 (112 $\mathrm{mg}, 85 \%)$ as a colorless oil: $[\alpha] 88^{\circ}\left(c 0.10, \mathrm{CHCl}_{3}\right)$; IR (neat): $2853(S)$, $1724(\mathrm{~s}), 1584(\mathrm{~m}), 1513(\mathrm{~s}), 1469(\mathrm{~s}), 1275(\mathrm{~s}), 1249(\mathrm{~s}), 1071$ (s), $970(\mathrm{~m}), 835$ (s), 807 (m), 775 (m); H NMR (500 MHz, $\left.\mathrm{CDCl}_{3}\right) \delta 7.25(\mathrm{~d}, J=9.0 \mathrm{~Hz}, 2 \mathrm{H}), 7.21(\mathrm{t}, J=8.3 \mathrm{~Hz}, 1 \mathrm{H})$, $6.86(\mathrm{~d}, J=9.0 \mathrm{~Hz}, 2 \mathrm{H}), 6.78(\mathrm{~d}, J=8.4 \mathrm{~Hz}, 1 \mathrm{H}), 6.74(\mathrm{~d}$, $J=7.6 \mathrm{~Hz}, 1 \mathrm{H}), 5.75-5.85(\mathrm{~m}, 1 \mathrm{H}), 5.64-5.72(\mathrm{~m}, 1 \mathrm{H}), 5.41$ (ddt, $J=15.1,10.8,2.1 \mathrm{~Hz}, 1 \mathrm{H}), 5.25-5.34(\mathrm{~m}, 2 \mathrm{H}), 4.42(\mathrm{~d}$, $J=3.2 \mathrm{~Hz}, 2 \mathrm{H}), 4.23(\mathrm{dd}, J=8.5,3.5 \mathrm{~Hz}, 1 \mathrm{H}), 3.97(\mathrm{~m}, 1 \mathrm{H})$, $3.80(\mathrm{~s}, 3 \mathrm{H}), 3.74(\mathrm{~s}, 3 \mathrm{H}), 3.71(\mathrm{dd}, J=16.3,9.4 \mathrm{~Hz}, 1 \mathrm{H}), 3.30$ (dd, $J=16.3,2.0 \mathrm{~Hz}, 1 \mathrm{H}), 2.41-2.52(\mathrm{~m}, 1 \mathrm{H}), 2.28-2.37(\mathrm{~m}$, $1 \mathrm{H}), 2.21-2.29(\mathrm{~m}, 1 \mathrm{H}), 1.80(\mathrm{~m}, 1 \mathrm{H}), 1.68(\mathrm{dd}, J=14.9,8.3$ $\mathrm{Hz}, 2 \mathrm{H}), 1.43$ (dd, $J=15.2,7.8 \mathrm{~Hz}, 1 \mathrm{H}), 0.90(\mathrm{~s}, 9 \mathrm{H}), 0.83$ (d, $J=6.8 \mathrm{~Hz}, 3 \mathrm{H}), 0.23(\mathrm{~s}, 3 \mathrm{H}), 0.12(\mathrm{~s}, 3 \mathrm{H}) ;{ }^{13} \mathrm{C}$ NMR $(125$ $\left.\mathrm{MHz}, \mathrm{CDCl}_{3}\right) \delta 170.0,159.1,156.6,139.0,131.2,130.4$, 129.9, 129.4, 129.3, 129.2, 128.4, 124.6, 122.6, 113.7, 109.3, 74.6, 72.3, 71.4, 70.3, 55.5, 55.2, 39.0, 37.8, 37.7, 37.3, 36.7, 25.9, 17.9, 13.0, -4.3, -4.5; high resolution mass spectrum (ES, $\mathrm{Na}) \mathrm{m} / \mathrm{z} 617.3265\left[(\mathrm{M}+\mathrm{Na})^{+}\right.$; calcd for $\mathrm{C}_{35} \mathrm{H}_{50} \mathrm{O}_{6} \mathrm{SiNa}$ : 617.3275].

(26) Smith, A. B., III; Adams, C. M.; Kozmin, S. A. J. Am. Chem. Soc. 2001, 123, 990-991.

(27) Dess, D. B.; Martin, J. C. J. Am. Chem.Soc. 1991, 113, 72777287.

(28) Lampilas M.; Lett, R. Tetrahedron Lett. 1992, 33, 777-780.

(29) Bogucki, D. E.; Chalton, J. L. Can J. Chem. 1997, 75,17831794.

(30) Furber, M.; Taylor, R. J. K. J. Chem. Soc. Perkin. Trans. 1 1986, 1809-1815. Furber, M.; Taylor, R. J. K. J.; Burford, S. C. Tetrahedron Lett. 1985, 26, 3285-3288.

(31) Overman, L. E.; Taylor, G. F.; Petty, C. B.; Jessup, P. J. J. Org. Chem. 1978, 43, 2164-2167.

(32) To a solution of (-)-18 (7 mg, $0.012 \mathrm{mmol})$ in acetone $(0.8$ $\mathrm{mL})$ was sequentially added $N, N$-diisopropylethylamine $(3.4$ $\mathrm{mg}, 4.6 \mu \mathrm{L}, 0.026 \mathrm{mmol}$ ) and isobutylchloroformate $(3.2 \mathrm{mg}$, $3.0 \mu \mathrm{L}, 0.024 \mathrm{mmol})$ at $0{ }^{\circ} \mathrm{C}$. The reaction mixture was stirred at room temperature for 1 hour, and then a solution of sodium azide $(7.8 \mathrm{mg}, 0.119 \mathrm{mmol})$ in distilled $\mathrm{H}_{2} \mathrm{O}(0.4 \mathrm{~mL})$ was added. The resulting mixture was stirred at room temperature for an additional $30 \mathrm{~min}$. Brine $(10 \mathrm{~mL})$ was added and the aqueous phase extracted with ethyl acetate $(2 \times 20 \mathrm{~mL})$. The combined organic phases were dried over $\mathrm{MgSO}_{4}$, filtered and concentrated in vacuo. The residue was azeotropically dried with benzene $(2 \times 1 \mathrm{~mL})$ and then dissolved in toluene $(2 \mathrm{~mL})$ and heated at reflux for $15 \mathrm{~min}$. 2-(Trimethylsilyl)-ethanol was added in one portion and the mixture was heated at reflux for an additional $10 \mathrm{~min}$. The mixture was then cooled to room temperature and concentrated in vacuo. Flash chromatography (ethyl acetate/hexanes, 1:20) afforded (-)-3 (7.2 mg, 86\%) as a colorless oil: $[\alpha]-15.0^{\circ}\left(c 0.10, \mathrm{CH}_{2} \mathrm{Cl}_{2}\right)$; IR (neat): 3200 3400 (br, m), 2856 (s), 1725 (s), 1681 (m), 1581 (m), 1504 (m), 1462 (s), 1259 (s), 1066 (s), 836 (s), 804 (s), 665 (s); ${ }^{1} \mathrm{H}$ NMR $\left(500 \mathrm{MHz}, \mathrm{C}_{6} \mathrm{D}_{6}\right) \delta 6.91(\mathrm{t}, J=8.0 \mathrm{~Hz}, 1 \mathrm{H}), 6.80-6.89$ $(\mathrm{m}, 1 \mathrm{H}), 6.70(\mathrm{~d}, J=8.1,1 \mathrm{H}), 6.56(\mathrm{~d}, J=7.6 \mathrm{~Hz}, 1 \mathrm{H}), 5.69$ $(\mathrm{d}, J=10.8 \mathrm{~Hz}, 1 \mathrm{H}), 5.40-5.47(\mathrm{~m}, 1 \mathrm{H}), 5.31-5.40(\mathrm{~m}, 2 \mathrm{H})$, 
4.62-4.78 (m, 1H), $4.49(\mathrm{~m}, 1 \mathrm{H}), 4.16(\mathrm{t}, J=8.2 \mathrm{~Hz}, 2 \mathrm{H}), 3.70$ $(\mathrm{dd}, J=16.1,8.3 \mathrm{~Hz}, 1 \mathrm{H}), 3.20(\mathrm{dd}, J=16.1,4.1 \mathrm{~Hz}, 1 \mathrm{H})$, 2.33-2.49 (m, 2H), $2.11(\mathrm{~m}, 1 \mathrm{H}), 1.68(\mathrm{~m}, 1 \mathrm{H}), 1.59-1.70(\mathrm{~m}$, $2 \mathrm{H}), 1.50-1.58(\mathrm{~m}, 1 \mathrm{H}), 1.10(\mathrm{~s}, 9 \mathrm{H}), 1.03(\mathrm{~s}, 9 \mathrm{H}), 0.82-0.90$ (m, 5H), 0.28 (s, 6H), $0.16(\mathrm{~s}, 3 \mathrm{H}), 0.11(\mathrm{~s}, 3 \mathrm{H}),-0.11$ (s, 9H); ${ }^{13} \mathrm{C}$ NMR $\left(125 \mathrm{MHz}, \mathrm{C}_{6} \mathrm{D}_{6}\right) \delta 167.9,153.2,153.0,138.7$, 131.2, 129.6, 128.9, 128.8, 126.7, 123.3, 118.1, 104.0, 74.2, 72.1, 63.0, 38.3, 38.1, 37.5, 36.2, 35.9, 26.0, 25.7, 18.3, 18.1, 17.6, 1.1, -1.9, -4.2, -4.3, -4.6, -4.7; high resolution mass spectrum $(\mathrm{ES}, \mathrm{Na}) \mathrm{m} / \mathrm{z} 726.4037\left[(\mathrm{M}+\mathrm{Na})^{+}\right.$; calcd for $\left.\mathrm{C}_{37} \mathrm{H}_{65} \mathrm{NO}_{6} \mathrm{Si}_{3} \mathrm{Na}: 726.4017\right]$.

(33) A solution of (-)-3 (4.2 mg, $0.006 \mathrm{mmol})$ in dry THF (1 mL) was treated with sodium bis(trimethylsilyl)amide $(1.0 \mathrm{M}$ in THF, $9 \mu \mathrm{L}, 0.009 \mathrm{mmol})$ for $5 \mathrm{~min}$ at $0{ }^{\circ} \mathrm{C}$. A solution of $4(1.5$ $\mathrm{mg}, 0.012 \mathrm{mmol})$ in dry benzene $(0.1 \mathrm{~mL})$ was added. The resulting mixture was stirred at $0{ }^{\circ} \mathrm{C}$ for $10 \mathrm{~min}$ before being quenched with saturated $\mathrm{NH}_{4} \mathrm{Cl}(3 \mathrm{~mL})$ and extracted with ether $(2 \times 15 \mathrm{~mL})$. The combined organic phases were washed with brine, dried over $\mathrm{MgSO}_{4}$, filtered and concentrated. Flash chromatography (ethyl acetate/hexanes, 1:10) provided (-)-20 (3.9 mg, 81\%) as a colorless oil: $[\alpha]-20.0^{\circ}\left(c 0.20, \mathrm{CH}_{2} \mathrm{Cl}_{2}\right)$; IR (neat): 3587 (m), 2926 (s), 2854 (s), 1728 (s), 1581 (m), $1456(\mathrm{~m}), 1382(\mathrm{~m}), 1260(\mathrm{~s}), 1066(\mathrm{~s}), 969(\mathrm{~m}), 860(\mathrm{~m}), 803$ (s); ${ }^{1} \mathrm{H}$ NMR $\left(500 \mathrm{MHz}, \mathrm{C}_{6} \mathrm{D}_{6}\right) \delta 7.54(\mathrm{t}, J=11.5 \mathrm{~Hz}, 1 \mathrm{H})$, $6.90(\mathrm{t}, J=7.9 \mathrm{~Hz}, 1 \mathrm{H}), 6.65-6.75(\mathrm{~m}, 2 \mathrm{H}), 6.53-6.62(\mathrm{~m}, 2 \mathrm{H})$, $6.45(\mathrm{~d}, J=11.5 \mathrm{~Hz}, 1 \mathrm{H}), 5.89(\mathrm{dt}, J=14.1,7.4 \mathrm{~Hz}, 1 \mathrm{H}), 5.54-$ $5.65(\mathrm{~m}, 2 \mathrm{H}), 5.33-5.45(\mathrm{~m}, 2 \mathrm{H}), 4.51-4.59(\mathrm{~m}, 1 \mathrm{H}), 4.18(\mathrm{t}$, $J=7.6 \mathrm{~Hz}, 2 \mathrm{H}), 3.69(\mathrm{dd}, J=16.0,8.1 \mathrm{~Hz}, 1 \mathrm{H}), 3.19(\mathrm{dd}$, $J=16.0,4.0 \mathrm{~Hz}, 1 \mathrm{H}), 2.53-2.69(\mathrm{~m}, 2 \mathrm{H}), 2.10-2.19(\mathrm{~m}, 1 \mathrm{H})$, $1.85-1.96(\mathrm{~m}, 1 \mathrm{H}), 1.75-1.85(\mathrm{~m}, 2 \mathrm{H}), 1.65-1.75(\mathrm{~m}, 2 \mathrm{H}), 1.12$ $(\mathrm{s}, 9 \mathrm{H}), 1.02(\mathrm{~s}, 9 \mathrm{H}), 0.92(\mathrm{~d}, J=6.6 \mathrm{~Hz}, 3 \mathrm{H}), 0.88-0.97(\mathrm{~m}$, $2 \mathrm{H}), 0.73(\mathrm{t}, J=7.5 \mathrm{~Hz}, 3 \mathrm{H}), 0.28(\mathrm{~s}, 9 \mathrm{H}), 0.16(\mathrm{~s}, 3 \mathrm{H}), 0.11$ (s, 3H), $-0.10(\mathrm{~s}, 6 \mathrm{H}) ;{ }^{13} \mathrm{C}$ NMR $\left(125 \mathrm{MHz}, \mathrm{C}_{6} \mathrm{D}_{6}\right) \delta 170.0$, 166.9, 153.6, 153.0, 142.3, 138.8, 137.0, 131.2, 129.2, 128.6, 127.0, 124.9, 123.3, 121.1, 121.0, 118.0, 73.6, 72.1, 65.0, 38.3, 38.0, 37.5, 37.0, 36.2, 26.0, 25.7, 20.6, 18.3, 18.1, 17.4, $13.7,1.1,-2.0,-4.2,-4.3,-4.6,-4.7$; high resolution mass spectrum $(\mathrm{ES}, \mathrm{Na}) \mathrm{m} / \mathrm{z} 834.4618\left[(\mathrm{M}+\mathrm{Na})^{+}\right.$; calcd for $\mathrm{C}_{44} \mathrm{H}_{73} \mathrm{NO}_{7} \mathrm{Si}_{3} \mathrm{Na}$ : 834.4618].

Article Identifier:

1437-2096,E;2001,0,SI,1019,1023,ftx,en;Y04901ST.pdf 